\title{
Urethrastriktur - en nasjonal oppgave
}

\author{
Bruken av ordet nasjonal griper om seg - vi har fått nasjonale retningslinjer, nasjonale kompetansesentre, \\ nasjonale kvalitetsregistre og nasjonale oppgaver. Hva er egentlig galt med ordene norsk, landsdekkende \\ og landsfunksjoner?
}

Ordene nasjon og nasjonal har hatt en omskiftelig historie (1). Ordets opprinnelse er latin, natio, som betyr «der man er født». Studentene ved de eldste universitetene var i flere hundre år organisert som nasjoner etter hvilket geografiske område de kom fra (2). Denne tradisjonen lever fortsatt ved enkelte svenske universiteter, der medlemskap i studentnationer, som er sosiale studentforeninger, opprinnelig var forbeholdt studenter fra visse landsdeler (3).

Fra tiden rundt den franske revolusjon i 1789 ble ordet nasjon brukt om større befolkningsgrupper og statsdannelser, og på 1800-tallet og store deler av 1900-tallet var nasjonalstaten den viktigste og dominerende politiske enhet (1). Også i våre dager er nye stater ofte basert på befolkningsgrupper med felles kultur og identitet. Samtidig blir land med økt innvandring, blant annet Norge, etter hvert preget av mange og ulike kulturer - man snakker gjerne om flerkulturelle samfunn. De forente nasjoner (FN), som ble etablert i 1945, er en organisasjon av stater, men i USA og Canada omtales indianerstammer som nations for å vise respekt for deres særegne kultur og historie.

Ofte brukes ordet nasjonal for å angi autoritet, høytid eller opphøyethet. Vi snakker om nasjonal minneseremoni etter 22. juli (4) og om nasjonale løft, slik som gjenoppbyggingen av Norge etter den annen verdenskrig. Fullføringen av Nidarosdomen og byggingen av nytt operahus i Oslo er nasjonale oppgaver - de er hele landets ansvar, ikke bare de aktuelle byenes. Vi har nasjonaldag, nasjonalsang

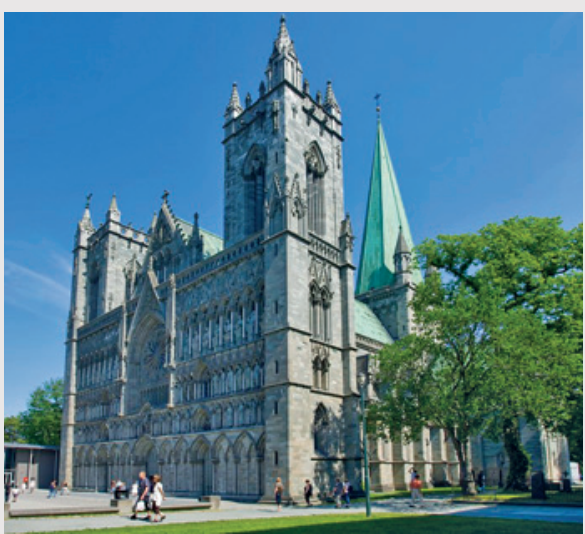

Hele landet står bak nasjonale oppgaver, slik som fullføringen av Nidarosdomen. Foto (c) Jose Fuste Raga/Corbis/SCANPIX og nasjonalforsamling. Men i andre sammenhenger kan ordet ha negative konnotasjoner - det er nok å nevne nasjonalisme, nasjonalsosialisme og Nasjonal Samling.

Store norske leksikon definerer nasjon som en gruppe mennesker med felles sosial og kulturell identitet, en statsdannelse eller en stat som omfatter en gruppe med felles identitet (1). Tilsvarende betegner nasjonal noe som hører til eller angår en nasjon, gjerne i motsetning til noe som er internasjonalt. Bokmålsordboka oppgir fire betydninger av ordet nasjonal: som hører til eller er særegen for et folk eller en kultur, patriotisk holdning, som gjelder hele landet, og innenlands (5).

\section{Nasjonale helsetjenester}

I de siste årene er ordet nasjonal mer og mer brukt $\mathrm{i}$ betydningen «som gjelder hele landet», og da i motsetning til regional og lokal. Helsedirektoratet opererer med nasjonale faglige retningslinjer og nasjonale veiledere (6), som innebærer at retningslinjene er overordnet retningslinjer i helseregioner og ved enkeltsykehus. Det er etablert en lang rekke nasjonale kompetansesentre for sykdommer og fagområder, og nye kommer stadig til (7). Disse har ansvar for å bygge opp kunnskap som andre deler av helsetjenesten kan dra nytte av. Samme oppgave har Nasjonalt kunnskapssenter for helsetjenesten (8). Det er også kommet nasjonale kvalitetsregistre for å studere langtidsresultater av ulike inngrep og prosedyrer; til å hjelpe seg har de Nasjonalt servicemiljø for medisinske kvalitetsregistre (9).

Noen spesialisthelsetjenestetilbud omtales ofte som regionsfunksjoner, flerregionsfunksjoner eller landsfunksjoner. Det siste er også omtalt som nasjonale oppgaver; nylig var tittelen på et fredagsforedrag for ansatte ved Rikshospitalet Urethrastriktur - en nasjonal oppgave.

\section{Norsk er bedre}

Bruken av ordet nasjonal i disse eksemplene er i manges ører oppstyltet og pompøs - for ikke å si komisk. Det er verken høytid eller kultur over noe så prosaisk som praktiske retningslinjer for diagnostikk og behandling av sykdom. Nasjonale kompetansesentre kan være svært små, nærmest kun et skilt på en dør - det er lite nasjonalt over dem, for å si det slik.

Det kan være mange årsaker til at bruken (og misbruken) av ordet nasjonal har tiltatt.
Det kan skyldes svak språkforståelse og uomtenksomhet. Noen kan ha et ønske om gjøre det litt finere og mer betydningsfullt enn det er grunnlag for. Alternativet statlig er altfor byråkratisk og autoritært, og kanskje føler noen at norsk kan oppfattes som diskriminerende overfor innvandrere.

Ordet nasjonal har altså mange valører og betydninger og bør i mange sammenhenger unngås. Ofte kan det med fordel strykes eller byttes ut med andre og mer egnede ord. Retningslinjer fra Helsedirektoratet kan betegnes norske retningslinjer eller Helsedirektoratets retningslinjer - det ville ikke gitt dem mindre tyngde, snarere tvert imot. Landsfunksjon er en god betegnelse for funksjoner som er tillagt kun ett sykehus. På samme måte er norsk, landsdekkende eller landsomfattende utmerkede beskrivelser av registre og kompetansesentre som er nettopp det.

\section{Petter Gjersvik}

petjense@online.no

Tidsskriftet

Jeg takker Erlend Hem og Are Brean for gode innspill.

Petter Gjersvik (f. 1952) er hudlege, dr.med., førsteamanuensis ved Oslo universitetssykehus og medisinsk redaktør i Tidsskriftet.

Litteratur

1. Berg OT. - nasjon. Store norske leksikon www.snl.no/nasjon (29.12.2011).

2. Nation (university). www.en.wikipedia.org/wiki/ Nation (university) (29.12.2011).

3. - Studentnation. www.sv.wikipedia.org/wiki/ Studentnation (29.12.2011).

4. Nasjonal minneseremoni for 22.7.2011. www.regjeringen.no/nb/sub/ minneseremoni.html?id=652066

5. - nasjonal. Bokmålsordboka. www.nobordbok.uio.no/perl/ordbok.cgi?OPP= nasjonal\&ordbok=bokmaal (29.12.2011)

6. Helsedirektoratet. Nasjonale faglige retningslinjer. www.helsedirektoratet.no/kvalitetplanlegging/nasjonale-retningslinjer/Sider/ default.aspx (29.12.2011).

7. Hem E. Nasjonalt kompetansesenter for...? Tidsskr Nor Legeforen 2010; 130: 1162

8. Nasjonalt kunnskapssenter for helsetjenesten. www.kunnskapssenteret.no/ (29.12.2011).

9. Nasjonalt servicemiljø for medisinske kvalitetsregistre. www.kvalitetsregistre.no/ kvalitetsregistre/category7.html (29.12.2011).

Mottatt 29.11.2011 og godkjent 16.1.2012. Medisinsk redaktør Raida Ødegaard. 